症例

$$
\begin{aligned}
& \text { 血浆交換により救命し得た血栓性血小板減少性 } \\
& \text { 紫斑病（TTP）の } 1 \text { 症例 } \\
& \text { 一本邦報告例の臨床病理学的検討一 } \\
& \begin{array}{lrrrr}
\text { 小林 } & \text { 裕 } & \text { 小野寺秀記 } & \text { 赤荻 } & \text { 照章 } \\
\text { 迫 } & \text { 雅美 } & \text { 林 英夫 } & \text { 藤田 } & \text { 洋一 } \\
& & \text { 京都第二赤十字病院内科 } &
\end{array}
\end{aligned}
$$

（昭和60年 3 月 25 日受付）

\title{
CASE REPORT OF THROMBOTIC THROMBOCYTOPENIC PURPURA (TTP) WHICH RESPONDED QUITE WELL TO PLASMA EXCHANGE \\ -Clinicopathological Studies on TTP Cases which Appeared \\ In the Japanese Literatures-
}

\author{
Yutaka Kobayashi, Hideki Onodera, Teruaki Akaogi, Masami Sako, \\ Hideo Hayashi and Yoichi Fujita \\ Department of Internal Medicine, The Kyoto Second Red Cross Hospital, Kyoto Japan
}

An interesting case of TTP, which responded dramatically well to plasma exchange (P.E.), is presented in detail. Besides, case reports that have appeared in the Japanese literatures in the last decade is summarized and reviewed in terms both of clinical features and of treatment, with emphasis on P.E. as a pertinent therapeutic procedure of the disease.

A 46-year-old man with macrohematuria and purpuric skin lesions at his shoulders with a week duration was admitted to the hospital on December 22, 1983, in suspicion of thrombocytopenia and hemolytic anemia presumed to be induced by some medicine prescribed for cold-like symptoms. By the hospital day 3, his consciousness became confused, then the clinical diagnosis of TTP was made. On the hospital day 7, he fell into unconsciousness despite combined use of corticosteroids and antiplatelet agents. Then he was started on P.E. And, on the hospital day 31, when the 13th procedure of P.E. was finished, his consciousness got clear and hematological findings improved. About 60 days after the current admission, almost all indices of hematological examination were within normal limit.

In Japan, sixty-three cases of TTP including this case have been reported during the last 10 years. On grounds of clinicopathological studies on these sixty-three cases of TTP in Japan, the following results were obtained: 1 ) The age of patients with TTP ranged from 8 to 63 , with mean value of 33.1.2) Ratio of male to female was 20 to 43. 3) Major symptoms which patients had consisted of purpuric skin lesions, hematuria, hemolytic anemia, psychiatric symptoms, febrile episodes, and renal dysfunction. 4) Twenty-five out of sixty-three patients $(39.7 \%)$ died within a year after the onset of the disease, while thirty-eight (60.3\%) survived: Eight among those sixty-three cases received P.E. Complete remission were attained in four out of those eight cases that were given P.E., while two out of those eight cases reached to partial remission. The rest two gained no beneficial effects.

Meanwhile, neither corticosteroid, antiplatelet agents nor any combination of these measures could exert any definite beneficial effects. Taken altogether, there have been few case reports of TTP in Japanese literatures so far and a large majority of those cases reported could not survive despite any combined usage of corticosteroid, antiplatelet agents or anticoaglants, whereas, P.E. turned out to be of significant value by comparison with any other regiments of treatment ever used. 


\section{はじめに}

血栓性血小板減少性紫斑病 thrombotic thrombocytopenic purpura (以下 TTP) は1925年 Moschowitz ${ }^{1}$ によりはじめて記載され, 血小板減 少, 細血管性溶血性貧血 microangiopathic hemolytic anemia (以下 MHA), 神経症状, 発熱, 腎障害を五徵とする比較的稀な疾患である。本邦 では1949年猪瀬帛がはじめて報告して以来100例 近い報告がある．治療に関し確立されたものはな く，1970年代より抗血小板剤が使用されはじめ, それ以前の糖質コルチコステロイド剂（以下 $\mathrm{CS}$ ，摘脾などに比し寛解率が上昇したが，それで も50 60\%であり，予後不良と考兄られた。最近 血浆交換 plasma exchange（以下 P.E.）が注目を 浴び本疾患の治療に期待をあつめている。 今回 我々はP.E.により救命し得た TTP の 1 例を経験 したので, 過去 10 年間の本邦報告例の若干の文献 的考察を加え報告する。

症例：46歳, 男性, 調理師

主訴：血尿, 紫斑.

既往歴，家族歷：特記すべきことなし。

現病歴：昭和58年 12 月 8 日発熱し, 感昌様症状 で近医受診。投薬にて一旦軽快するも，この頃よ り血尿に気づく１ 1 週後再度発熱し両肩から上腕 の紫斑に気づき再度近医受診，血小板数 $50,000 /$ $\mathrm{mm}^{3}$ を指摘され当科照会入院となる。
現症：意識清明, 体温 $37.2^{\circ} \mathrm{C}$, 皮膚及び可視粘 膜貧血様。四肢及び体幹に紫斑を認む。肝脾腫は 認めず。神経学的異常所見なし。

入院時検查 (表 1,2 ) : 尿潜血 (H), $\mathrm{Hb} 8.3 \mathrm{~g}$ / $\mathrm{d} l, \mathrm{WBC} 11,100 / \mathrm{mm}^{3}$, 血小板数 $10,000 / \mathrm{mm}^{3}$, 八 プトグロビン $10 \mathrm{mg} / \mathrm{d} l$ 以下, LDH 2,360U, T.Bil. $2.0 \mathrm{mg} / \mathrm{d} l$. 末梢血塗末標本にて赤血球の破壊（破 砕赤血球)，大小不同を認める（図 1 ）。骨髄穿刺 では巨核球増加と赤芽球増加を認めた。凝固系は $\mathrm{FDP}$ のみ $40 \mu \mathrm{g} / \mathrm{m} l$ と異常值を示したが，他の検 査では特に異常を認めず，翌日再検では FDP も 正常値を示した。

入院後経過（図 2 ）：薬剤により惹起された急性 血小板減少と溶血性貧血の合併と考光，大量 intact immunoglobulin, prednisolone $60 \mathrm{mg} /$ 日の 経口投与を開始するも，血液学的に悪化し骨䯣で の赤芽球は著増した。院 3 日目，動摇する見当 識障害, 呕吐の出現, BUN, 血清クレアチニンの 軽度上昇を認め,この時点で TTP と診断した。脳 波では $\theta$ 波の他，時々burstを認めた。 Methylprednisolone のパルス療法, dipyridamole（以下 DPM）（120mg/日点滴静注），dextran-sulfate $(2,400 \mathrm{mg}$ /日点滴静注), FUT-175 (40mg $\times 2$ /日 点滴静注）を加薬するも改善がみられず，入院 7 日目に突然昏睡となり除皮質硬直を示した。同日 より 1 回30単位の新鮮凍結血浆 fresh frozen

表 1 入院時検查

\begin{tabular}{|c|c|c|c|c|c|}
\hline \multicolumn{2}{|c|}{ Peripheral blood } & \multicolumn{2}{|c|}{ Bone marrow blood } & \multicolumn{2}{|l|}{ 血液凝固系 } \\
\hline $\mathrm{RBC}$ & $250 \times 10^{4} / \mathrm{mm}^{3}$ & $\mathrm{NCC}$ & $23.8 \times 10^{4} / \mathrm{mm}^{3}$ & 出血時間 & 15分以上 \\
\hline $\mathrm{Hb}$ & $8.3 \mathrm{~g} / \mathrm{d} l$ & Promyelo. & $0.4 \%$ & 凝固時間 & 9分 \\
\hline $\mathrm{Ht}$ & $25.3 \%$ & Myelo. & $6.8 \%$ & 毛細管低抗 & 陰圧法 (一) \\
\hline Reti. & $84 \%$ & Meta. & $8.0 \%$ & PT & 12.6 秒 \\
\hline PLT & $10,000 / \mathrm{mm}^{3}$ & St. & $18.4 \%$ & & $94 \%$ \\
\hline WBC & $11,100 / \mathrm{mm}^{3}$ & Seg. & $8.0 \%$ & トロンボテスト & $100 \%$ \\
\hline Myelo. & $1 \%$ & Eo. & $0.8 \%$ & $\mathrm{Ca}$ 再加時間 & 180 秒 \\
\hline Meta. & $1 \%$ & Mo. & $0.4 \%$ & APTT & 48.0 秒 \\
\hline St. & $12 \%$ & Lym. & $7.6 \%$ & プロトロンビン消費時間 & 46.8 秒 \\
\hline Seg. & $64 \%$ & Plas. & $0.4 \%$ & フィブリノーゲン & $390 \mathrm{mg} / \mathrm{d} l$ \\
\hline Eo. & $1 \%$ & Ery. blast & & FDP & $40 \mu \mathrm{g} / \mathrm{m} l$ \\
\hline Lym. & $13 \%$ & B. & $7.6 \%$ & AT III & $30 \mathrm{mg} / \mathrm{d} l$ \\
\hline Aty. & $2 \%$ & P. & $40.4 \%$ & & \\
\hline Mo. & $6 \%$ & $\begin{array}{cc}\mathrm{O} . & \\
\mathrm{M}: \mathrm{E} & 1\end{array}$ & 0 & & \\
\hline
\end{tabular}


表 2 入院時検査

\begin{tabular}{|c|c|c|c|c|}
\hline \multirow[t]{6}{*}{ 尿 } & \multicolumn{2}{|c|}{ タンパク (土) } & \multicolumn{2}{|c|}{$19.5 \mathrm{mg} / \mathrm{d} l$} \\
\hline & 糖 & $(-)$ & Crea. & $\mathrm{mg} / \mathrm{d} l$ \\
\hline & 潜血 & (H) & $\mathrm{UA}$ & $\mathrm{mg} / \mathrm{d} l$ \\
\hline & ウロビリ & 正 & $\mathrm{Na}$ & $\mathrm{mEq} / \mathrm{l}$ \\
\hline & ビリルビ & ジン & 3.8 & $\mathrm{mEq} / \mathrm{l}$ \\
\hline & & $(-)$ & 103 & $\mathrm{mEq} / \mathrm{l}$ \\
\hline \multirow[t]{5}{*}{ 沈椬 } & $\mathrm{RBC} \quad 4$ & 40-50/1視野 & $\mathrm{Ca}$ & $\mathrm{mEq} / \mathrm{l}$ \\
\hline & WBC 2 & $20-30 / 1$ 視野 & & \\
\hline & epithel. & $4-5 / 1$ 視野 & 273 & $\mu \mathrm{g} / \mathrm{d} l$ \\
\hline & 硝子円柱 & 主 $\quad 1 / 1$ 視野 & UIBC & $\mu \mathrm{g} / \mathrm{d} l$ \\
\hline & 顆粒円柱 & $1-2 / 1$ 視野 & フェリチン & $\mathrm{ng} / \mathrm{ml}$ \\
\hline \multirow[t]{6}{*}{ T.P. } & & $6.3 \mathrm{~g} / \mathrm{d} l$ & $\mathrm{VB}_{12}$ & $\mathrm{pg} / \mathrm{m} l$ \\
\hline & Alb. & $60.5 \%$ & 葉酸 & $\mathrm{ng} / \mathrm{m} l$ \\
\hline & $\alpha_{1}-g l$ & $6.6 \%$ & 血清へモグロビン 0.2 & $\mathrm{mg} / \mathrm{d} l$ \\
\hline & $\alpha_{2}-\mathrm{gl}$ & $6.6 \%$ & ハプトグロビン $10 \mathrm{mg}$ & $\mathrm{g} / \mathrm{d} l$ 以下 \\
\hline & $\beta \cdot \mathrm{gl}$. & $16.8 \%$ & $\operatorname{IgG}$ & $\mathrm{mg} / \mathrm{d} l$ \\
\hline & $\gamma$-gl. & $9.5 \%$ & $\operatorname{IgA}$ & $\mathrm{mg} / \mathrm{d} l$ \\
\hline \multicolumn{2}{|c|}{ T.Bil. } & $2.0 \mathrm{mg} / \mathrm{d} l$ & $\operatorname{IgM}$ & $\mathrm{mg} / \mathrm{d} l$ \\
\hline \multicolumn{2}{|c|}{ D.Bil. } & $0.6 \mathrm{mg} / \mathrm{d} l$ & $\operatorname{IgE}$ & $\mathrm{U} / \mathrm{m} l$ \\
\hline \multicolumn{2}{|c|}{ GOT } & $33 \mathrm{U}$ & $\mathrm{C}_{3}$ & $\mathrm{mg} / \mathrm{d} l$ \\
\hline \multicolumn{2}{|l|}{ GPT } & $15 \mathrm{U}$ & $\mathrm{C}_{4}$ & $1 \mathrm{mg} / \mathrm{d} l$ \\
\hline \multicolumn{2}{|l|}{$\mathrm{LDH}$} & $2360 \mathrm{U}$ & ANF & 倍 \\
\hline \multicolumn{2}{|l|}{ LAP } & $120 \mathrm{GRU}$ & $42.1 \mathrm{CH}$ & $\mathrm{H}_{50} \mathrm{U} / \mathrm{m} l$ \\
\hline \multicolumn{2}{|l|}{ Al-p } & $4.6 \mathrm{KA}$ & $1.5 \mu \mathrm{g}$ & $/ \mathrm{m} l$ 以下 \\
\hline \multicolumn{2}{|c|}{$\gamma$-GTP } & $24 \mathrm{mU}$ & DNA テスト & 320 倍 \\
\hline \multicolumn{2}{|c|}{ Ch.E. } & $0.64 \Delta \mathrm{pH}$ & サイロイドテスト & $(-)$ \\
\hline \multicolumn{2}{|l|}{ ZTT } & $13.2 \mathrm{KU}$ & マイクロゾームテスト & $(-)$ \\
\hline \multicolumn{2}{|c|}{ LDHアイソ 1} & $22.9 \%$ & 抗血小板抗体 & $(-)$ \\
\hline & 2 & $38.8 \%$ & 抗 ENA 抗体 & $(-)$ \\
\hline & 3 & $18.1 \%$ & STS & $(-)$ \\
\hline & 4 & $9.2 \%$ & $\mathrm{HBsAg}$ & $(-)$ \\
\hline & 5 & $11.0 \%$ & $\mathrm{HBsAb}$ & $(+)$ \\
\hline \multicolumn{2}{|l|}{ FBS } & $116 \mathrm{mg} / \mathrm{d} l$ & ESR & $7 \mathrm{~mm} / \mathrm{hr}$ \\
\hline \multicolumn{2}{|c|}{ T.chol. } & $255 \mathrm{mg} / \mathrm{d} l$ & CRP & $2+$ \\
\hline \multicolumn{2}{|l|}{ T.G. } & $164 \mathrm{mg} / \mathrm{d} l$ & RA & $(-)$ \\
\hline \multicolumn{2}{|c|}{$\mathrm{CPK}$} & $63 \mathrm{IU} / 30^{\circ} \mathrm{C}$ & ASO & $0 \mathrm{Tu}$ \\
\hline \multicolumn{2}{|c|}{ アミラーゼ } & $94 \mathrm{U}$ & クームステスト & $(-)$ \\
\hline
\end{tabular}

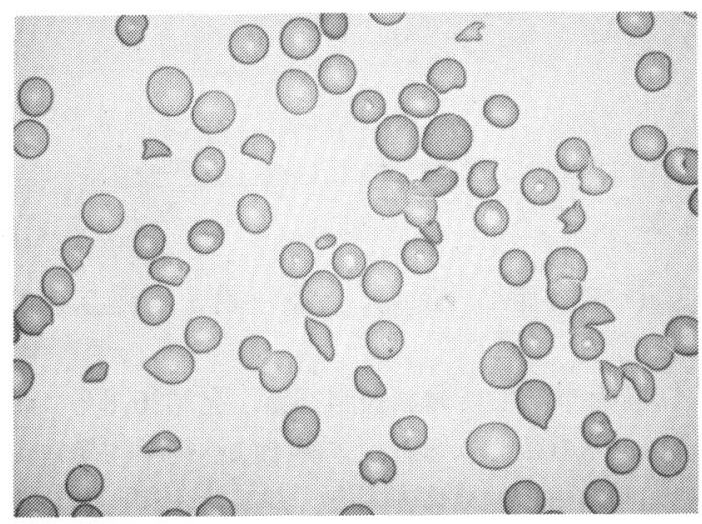

図 1 赤血球の大小不同, 破壊像を認める. plasma（以下 FFP）を使用し，P.E.を開始した。 また呼吸状態も悪化したため気管切開を施行し た. 翌日第 2 回目 P.E.施行後より昏睡から脱した が，血小板数は $10,000 / \mathrm{mm}^{3}$ 前後, $\mathrm{Hb} 5.0 \mathrm{~g} / \mathrm{d} l$ 前 後を持続し改善がみられないため，ほぼ連日にわ たりP.E.を施行した。意識は徐々に改善し，入院 21日目，P.E.第10回目施行後より意識は清明とな り，脳波も正常となり，血液学的にも一過性の血 小板数の上昇を認めるようになった. 入院 31 日目, P.E.第13回目施行後より血小板数も順調に改善 乙，入院60日目頃には血液学的に異常を認めてい ない，入院50日目頃より肝機能障害，全身に中毒 疹を認めたが徐々に改善し，DPM（400mg/日）, ticlopidine hydrochloride (以下 TP) (300mg/日) を維持療法とし，入院119日目に退院となった。以 後，外来にて経過観察中であるが，再発はみられ ず順調である。

な扮自験例で経過中，患者 platelet poor plasma (以下 PPP) と健常人 platelet rich plasma (以下 PRP) にて血小板凝集能を観察してみた(表 3 ). 部分寛解状態であった昭和59年 1 月 13 日に は，患者 PPP と健常人 PRP では，コントロール の健常人 PPP と他健常人 PRP に比し, 最大凝集 率は ADP 凝集では49.3/39.8,37.8/22.8, ボスミ ン凝集では63.8/25.9，48.7/21.0とともに六進し て怙り，患者血浆中に platelet aggregating factor $(\text { 以下 } \mathrm{PAF})^{3) 4}$ )様物質の存在が想定された。一 方完全寛解状態の 2 月16日にはコントロールに比 し，ボスミン凝集では50.0/26.7, 54.4/31.1とな お差を認めるが，ADP 凝集では20.3/24.2, 25.6/ 25.8 差を認めなかった。な拈 PRP は血小板数 $20 \sim 30 \times 10^{4} / \mathrm{mm}^{3}$ に調整したが，1月16日の患者 PRP は, 血小板数著減のため充分な血小板数が得 られていない。またコラーゲン凝集能では，いつ れの時期でもコントロールと差を認めなかった。

\section{本邦報告例の検討}

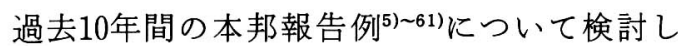
た.

対象, 方法：昭和49年から58年までの報告例(抄 録を含む）に自験例を加えた63例につき，性別， 年齢, 初発症状, 主訴, 経過中出現した臨床症候, 


1983
Dec. 22

PSL.
$60 \mathrm{mg}$
p.0.

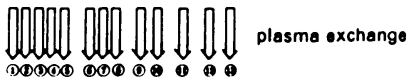
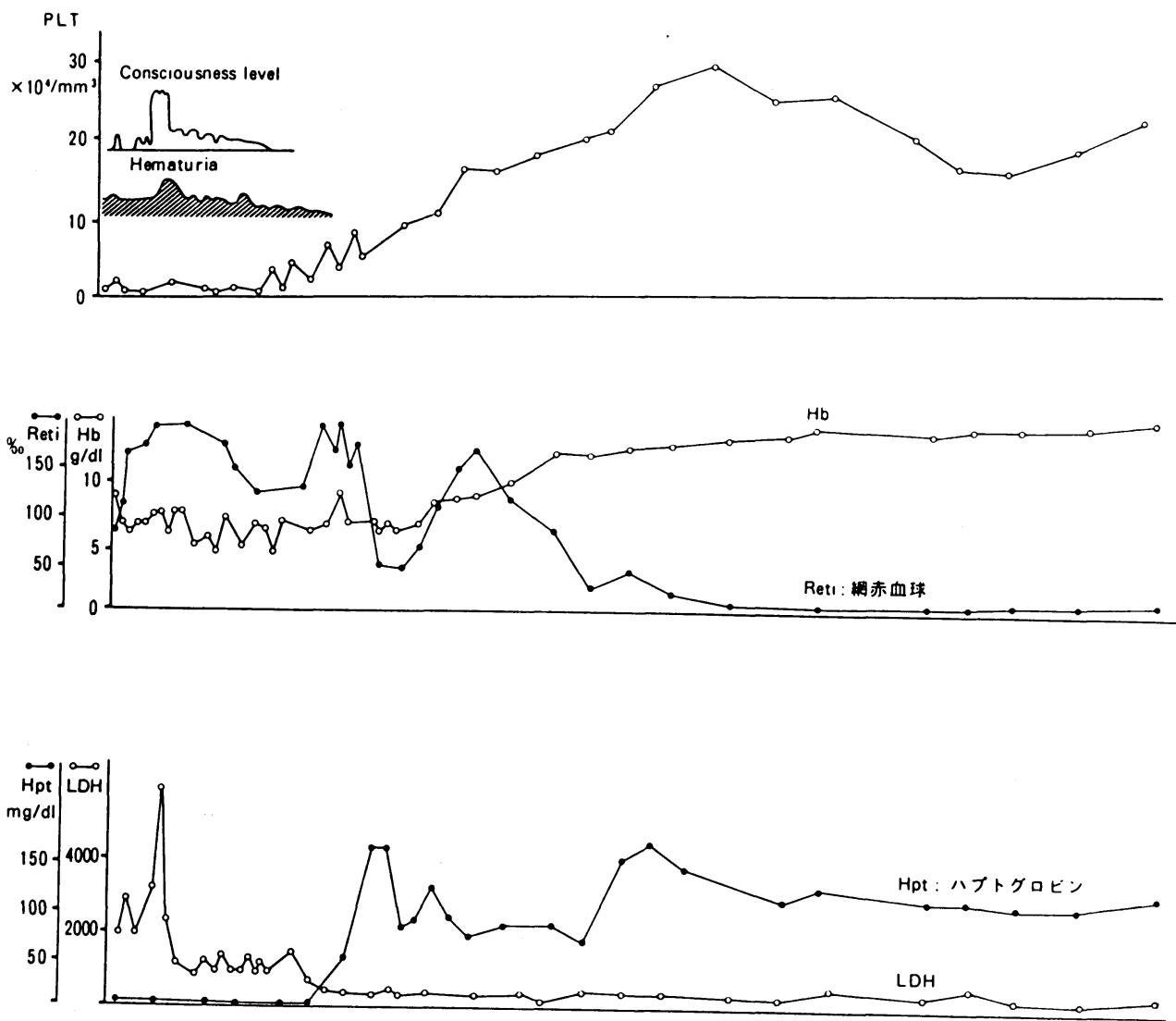

図 2 経 過 図

血小板数, $\mathrm{Hb}$ 量, 治療法と有効率, 生存期間を検 討した。

結果：

（i ）性別，年秢（図 3)

男性20例，女性43例，8歳から63歳まで各年齢 層にみられ，平均33.1歳，30歳台にピークをもつ。 （ii）初発症状（表 4 ），主訴（表 5 ），臨床症候 (表 6)

初発症状としては紫斑 $44.6 \%$, 発熱 $26.8 \%$, 頭 痛 $18.2 \%$ の順でみられ, 主訴では神経学的異常が $83.6 \%$ と圧倒的に多かった。経過中出現した臨床 症候では負血，血小板減少は $100 \%$ にられ，腎障 
表 3 患者 PPP と健常人 PRP の最大凝集率

1月13日

2 月 16 日

\begin{tabular}{|c|c|c|c|c|c|c|c|c|}
\hline & $P R P P P$ & 患 者 & $\begin{array}{c}\text { 健常人 } \\
\text { A }\end{array}$ & $\begin{array}{c}\text { 健常人 } \\
\text { B }\end{array}$ & $P R P P P$ & 患 者 & $\begin{array}{c}\text { 健常人 } \\
\mathrm{A}\end{array}$ & $\begin{array}{c}\text { 健常人 } \\
\mathrm{C}\end{array}$ \\
\hline \multirow{2}{*}{$\mathrm{ADP}$} & 患 者 & 6.5 & 3.2 & 9.5 & 患 者 & 27.0 & 8.8 & 9.2 \\
\hline & $\begin{array}{c}\text { 健常人 } \\
\mathrm{A}\end{array}$ & $\underline{49.3}$ & 30.9 & $\underline{39.8}$ & $\begin{array}{c}\text { 健常人 } \\
\mathrm{A}\end{array}$ & 20.3 & 23.0 & $\underline{24.2}$ \\
\hline $2 \times 10^{-6} \mathrm{M}$ & $\begin{array}{c}\text { 健常人 } \\
\mathrm{B}\end{array}$ & $\underline{37.8}$ & $\underline{22.8}$ & 34.0 & $\begin{array}{c}\text { 健常人 } \\
\text { C }\end{array}$ & $\underline{25.6}$ & $\underline{25.8}$ & 31.1 \\
\hline \multirow{2}{*}{ ボスミン } & 患 者 & 7.9 & 7.1 & 5.0 & 患 者 & 55.4 & 43.1 & 41.5 \\
\hline & $\begin{array}{c}\text { 健常人 } \\
\text { A }\end{array}$ & $\underline{63.9}$ & 25.9 & $\underline{25.9}$ & $\begin{array}{c}\text { 健常人 } \\
\text { A }\end{array}$ & $\underline{50.0}$ & 23.0 & $\underline{26.7}$ \\
\hline $2 \times 10^{-6} \mathrm{M}$ & $\underset{\mathrm{B}}{\text { 健常人 }}$ & $\underline{48.7}$ & $\underline{21.0}$ & 23.4 & $\begin{array}{c}\text { 健常人 } \\
\text { C }\end{array}$ & $\underline{54.4}$ & 31.1 & 29.7 \\
\hline
\end{tabular}

1 月13日(部分寛解期)の患者 PPP と健常人 PRP による最大凝集率は ADP,ボスミンともコントロー

ルに比し克進.

2 月16日(完全寛解期)ではADPによる凝集は差を認めない。

なお PRPは血小板数 $20 \sim 30 \times 10^{4} / \mathrm{mm}^{3}$ に調整したが， 1 月 13 日の患者 PRPは，血小板数著减のため充 分な血小板数が得られていない.

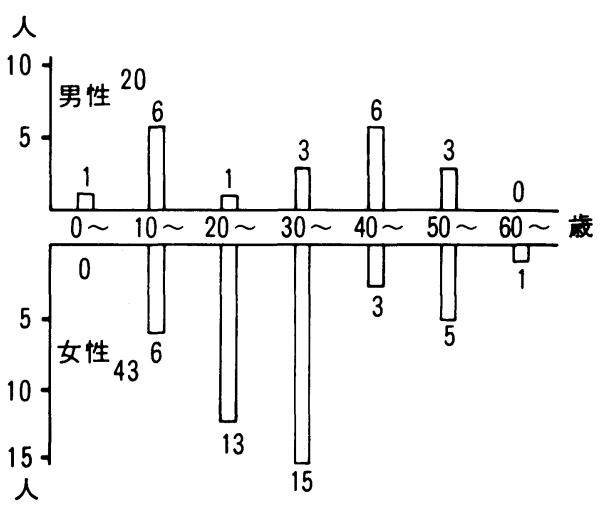

図 3 性別, 年歯

表 4 初発症状 (56例)

\begin{tabular}{|c|c|c|c|}
\hline & & 例 数 & 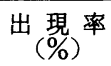 \\
\hline 紫 & 斑 & 25 & 44.6 \\
\hline 発 & 熱 & 15 & 26.8 \\
\hline 頭 & 痛 & 10 & 18.2 \\
\hline 意 識 障 & 害 & 4 & 7.1 \\
\hline 貧 & 血 & 4 & 7.1 \\
\hline 黄 & 㾝 & 3 & 5.4 \\
\hline 呕 & 気 & 2 & 3.6 \\
\hline 脱 & 力 & 1 & 1.8 \\
\hline
\end{tabular}

表 5 主訴(56例)

\begin{tabular}{|c|c|c|}
\hline & 例 数 & 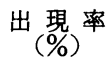 \\
\hline 神経学的異常 & 46 & 82.1 \\
\hline 紫 & 31 & 55.4 \\
\hline 発 熱 & 9 & 16.1 \\
\hline 負 血 & 8 & 14.3 \\
\hline
\end{tabular}

表 6 臨床症候

\begin{tabular}{|c|c|c|c|}
\hline & 全症例数 & 例 数 & 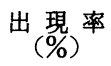 \\
\hline 血 & 57 & 57 & 100 \\
\hline 血小板减少 & 63 & 63 & 100 \\
\hline 神経学的異常 & 57 & 54 & 94.7 \\
\hline 疸 & 56 & 50 & 89.3 \\
\hline 熱 & 52 & 46 & 88.5 \\
\hline 腎 障 害 & 48 & 30 & 62.5 \\
\hline
\end{tabular}

害は62.5\%であった。

（iii）血小板数, $\mathrm{Hb}$ 量（図 4,5）

血小板減少は $30,000 / \mathrm{mm}^{3}$ 未満が半数以上, $\mathrm{Hb}$ 量は $8 \mathrm{~g} / \mathrm{d} l$ 末満が $2 / 3$ 以上であった。

（iv）治療法と有効率（表 7)

CSを使用したものが $82.5 \%$ ，抗血小板剤を使 


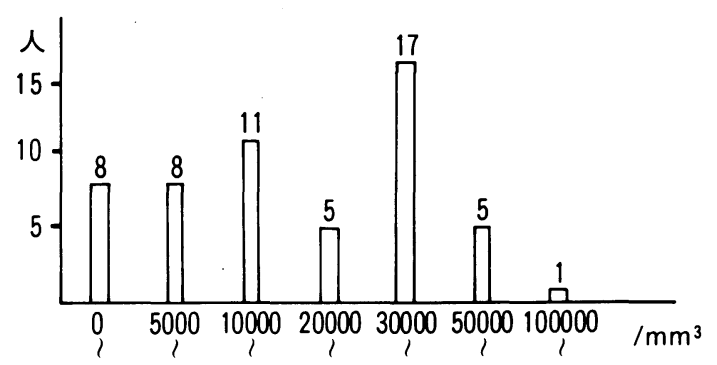

図 4 血小板数

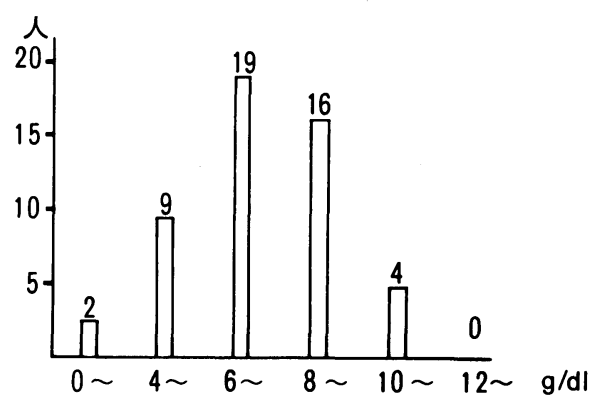

図 $5 \mathrm{Hb}$ 量

用したものが $52.4 \%$ と主流を占めている．P.E.は 8 例に施行され 6 例が有効となっている．摘脾は 3 例中 2 例が寛解維持療法として，1 例は P.E.な ぞ他療法無効例に施行されている．全体での有効 率は60.3\%であった。

（v）生存期間（図 6)

寛解に至らなかった約 $40 \%$ の多くは 4 週以内に 不幸の転帰をとっている。

（vi）P.E.症例の検討（表 8 ）

P.E.施行の本邦報告例 ${ }^{32) 43(49) 52) 58(60) 61)}$ に自験例 を加えた 8 例についてみると，1回交換量
表 7 治療方法と有効率

\begin{tabular}{|c|c|c|c|}
\hline & 例 数 & 有 効 & $\begin{array}{c}\text { 有効率 } \\
(\%)\end{array}$ \\
\hline 糖質コルチコステロイド & 11 & 7 & 63.6 \\
\hline 糖質コルチコステロイド＋その他 & 41 & 26 & 63.4 \\
\hline 抗血小板剤 & 2 & 2 & 100 \\
\hline 抗血小板剤＋その他 & 31 & 24 & 77.4 \\
\hline 抗凝固剂 & 2 & 1 & 50.0 \\
\hline 抗凝固剤+その他 & 22 & 11 & 50.0 \\
\hline 血漿交換十その他 & 8 & 6 & 75.0 \\
\hline 摘脾+その他 & 3 & 3 & 100 \\
\hline 記載なし & 7 & 1 & 14.3 \\
\hline 計 & 63 & 38 & 60.3 \\
\hline
\end{tabular}

$1,100 \sim 3,000 \mathrm{~m} l$, 平均約 $2,000 \mathrm{~m} l$, 回数は $2 \sim 23$ 回, 平均10回, 連日又は隔日にて施行されており, P.E. 開始は発症より $7 \sim 25$ 日後, 平均18.4日後で あった.P.E.施行時の神経症状は昏睡から傾眠, 単 麻痺など軽重, 種類はさまざまであった。血小板 数は8,000 33,000/ $\mathrm{mm}^{3}$, 平均 $16,000 / \mathrm{mm}^{3}$ で あった. 効果は完全寛解, 即ち神経症状と血液学 的所見とともに改善を認めたもの 4 例(50\%), 無 効 2 例（内 1 例は homolytic uremic syndrome $<$ 以下 HUS $>$ といら方が妥当と思われ, 神経症状 は頭痛のみ, 腎不全にて死亡している), 残り 2 例 は神経症状は改善をみたものの血液学的改善は一 過性（部分寛解）であった。

\section{総括と考案}

一疾患概念としての TTP 提唱の歴史は, むし ろ比較的旧聞に属するものではあるが, HUS ゃ MHA など症候論の上での類縁性が認められる疾 患概念との関わりを考えると，TTP はトピック

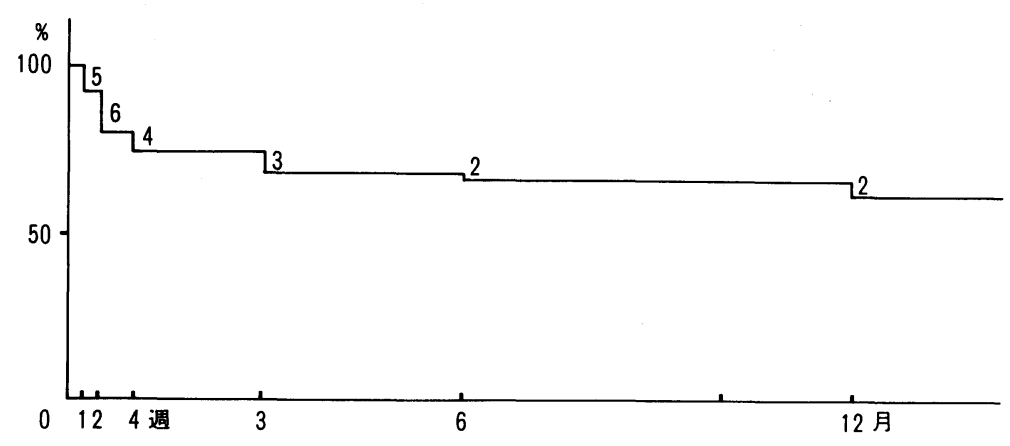

図 6 生存曲線 


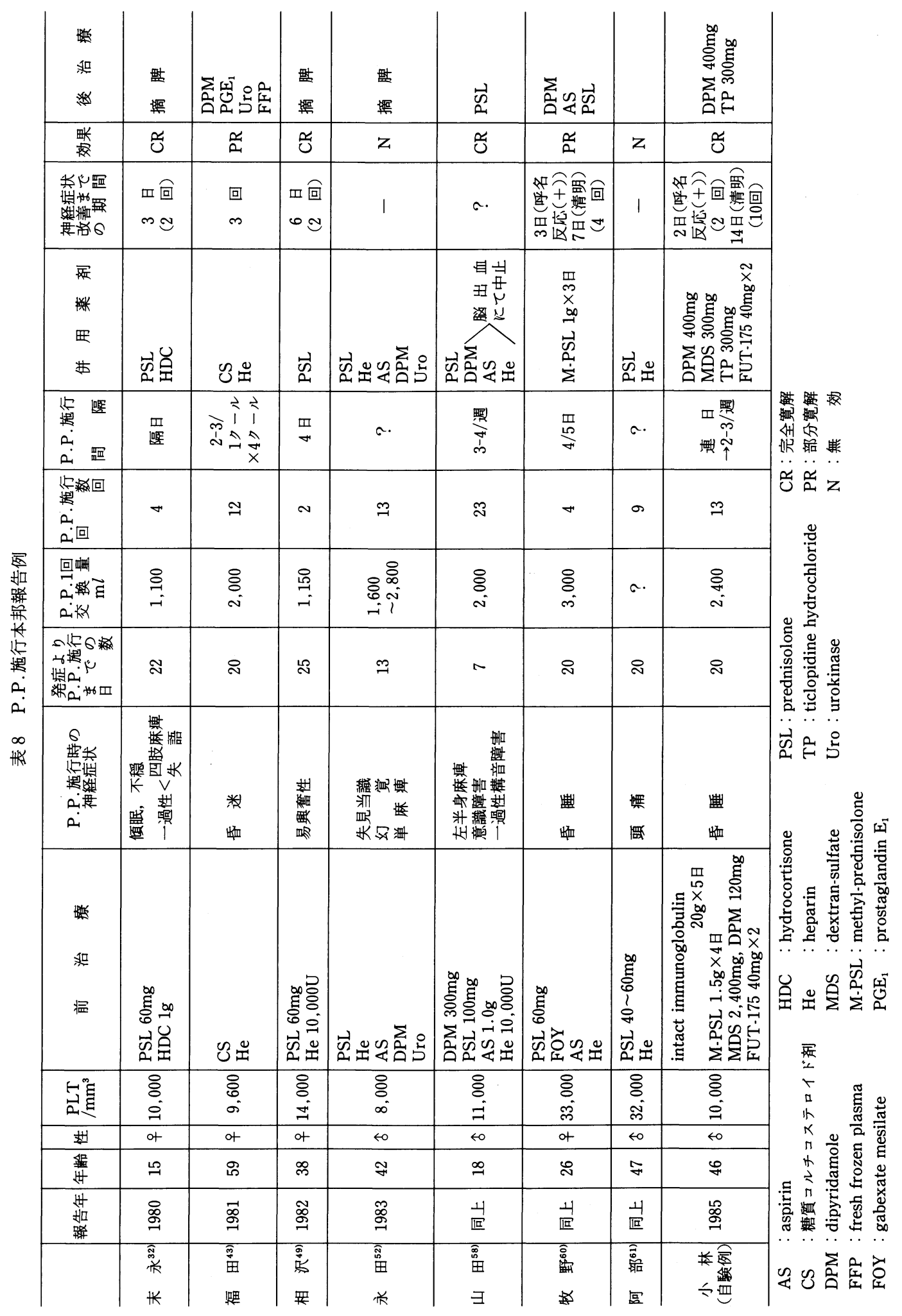


として比較的新しい歴史を有する様に見える。

最近 P.E.による寛解例の増加で，その作用機序 と病因の考察に興味がもたれているが，比較的稀 にしか経験されない事に加えて，しばしば急性に 経過し短期に死の転帰をとる為もあって, 臨床病 像や臨床病型の把握は勿論のことながら，その病 因論, 発症のメカニズム, 更には治療法などを含 めて, TTP とその類縁疾患の概念把握, 更に基礎 研究はそのほんの端緒を迎えたに過ぎないと言っ ても必ずしも過言ではない。

以下に自験例と文献例の検討をもとに，TTP の臨床像, 病因論, 治療法, 特にP.E.を中心に論 ずる.

（1）臨床病像または臨床病型について

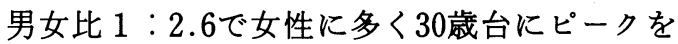
もつが各年秢層にみられている，小児にみられる 場合は特に HUS との異同が問題になるが本質的 には同一疾患による表現型の違いと考えられてい る. 小児と成人の個体の反応性の違いがその病変 の主座を腎とするか，脳とするかを決定している との考え方もある(18)62).

臨床症状では今までの報告に比し，腎障害がや や低率であったが，これは血尿のみの症例は血小 板減少による症状として腎障害に含めなかったた めと考兄れ，その他は大略同様であった。主症 状の神経症状は頭痛, 見当識障害から片麻疸, 構 語障害, 昏睡, 精神障害などあらゆる症状が出現 するが63)，他の中权神経疾患との鑑別は困難では ない，血小板減少は著明なものが多いが，脳出血 等致命的出血に至る症例58) 過は急峻であり，多くは 4 週以内に不幸の転帰を とるが，治療により部分寛解状態となり，その後 再発する症例や，SLE, 強直性脊椎炎での合併例 の報告にみる如く, MHA, 血小板減少などを断続 的に繰り返す“慢性型”ともいえるタイプの報告 例1231)44)妇みられた。

(2) 病因論について

病因は未だ不明であるが，SLEとの合 併(12)17)23)24)26)31)40157)63)がみられることや, circulating immune complex (以下 CIC) の存在す る例30)64)65)，IgMを血管壁に証明した例56)61166)な
ど免疫学的な機序も考えられている．本症例でも 皮膚の生検を施行したが，施行時期が寛解期には いってからのこともあり, IgM 等の沈着はみられ なかった。 その他ウイルス, 細菌感染, 薬剤, 妊 娠等により若起されたと考えられる症例もあ り 29167)68), TTPは一疾患というより, 症候群之捉 える方が妥当と考兄られている ${ }^{69)}$. 自験例では感 冒様症状にひきつづき発症して扣り，ウイルス， 薬剂等の関与が考学られた。

（3）治療法について

（i ）治療法概観

治療に関しては当初 CS, 摘脾が中心であった ${ }^{70)}$ が，1970年代より抗血小板剤の応用が加わ

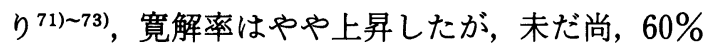
前後に留まり，効果も一定せず，故にこれら手法 の任意の組合せによる併用療法が施行されてい た。一方 P.E.は1980年代になり Bukowski ら ${ }^{74)}$, Myers ら ${ }^{75)}$ の報告にみる如く $82 \%, 81.5 \%$ の症例 に有効であったとされ，欧米ではほぼ確立された 治療法といえる. 置換液はFFP で, アルブミン等 他の置換液は無効であり，多くは 1 回 $2 \sim 3 l$ を使 用， 1 回目施行直後より劇的に神経症状の改善を みることが多いとされている，施行回数はBukowski らによると平均 5 回とされ，6週までに改 善するとされているが, 例外的に改善まで104週を 要した例や，全量1,400単位を要した例 ${ }^{74}$ などもあ る. 本邦報告例では平均回数 10 回と多く, $1 \sim 3$ 回 P.E.施行後に神経症状消失又は改善傾向がみ られている．神経症状の完全消失までにはP.E.施 行平均 4.2 回，6.6日を要している．血液学的改善 はそれより遅れ，再度悪化するもの，即ち一過性 の改善しか得られぬ事もある。自験例も第10回目 P.E.施行後意識清明であったが，血液学的改善は 一過性であり，13回目 P.E.施行後初めて持続的改 善に到達した。各症例毎に神経症状だけでなく血 小板数, LDH 等の指標も含めた改善まで施行し 続けるべきである，尚，血小板减少時の血小板輸 注は Harkness ら ${ }^{76}$ 㦗忌としているが，自験例 では再々ならず血小板数 $10,000 / \mathrm{mm}^{3}$ 以下での $\mathrm{P}$. E.施行を迫られ，やむなく血小板輸注後 P.E.を施 行した。 
P.E.の合併症, 副作用に関しては, 低血圧, らっ 血性心不全, クェン酸中毒など種々あげられてい る $^{77)}$. 疾病の重症度, 患者の精神的肉体的条件によ ク,リスクは変化するが, 体外循環を行なら以上, 慎重な適応決定と注意深い実施が必要である。本 症での施行中あるいはその直後の重篤な合併症の 報告はみあたらないが，劇症肝炎など，もともと リスクの非常に悪い患者に施行する場合は死亡例 の報告もあり，本症に対し P.E.施行の際も充分な 注意が必要である，本症では置換液に FFPを使 用するため, アナフィラキシー様反応，血清病様 反応，更に adult T-cell leukemia virus を含む各 種ウイルスの移入など大量輸血副反応と同様の問 題が指摘されている。自験例も招そらくFFPに よると思われる肝障害を来たしたが幸い軽度で大 過なく経過した.P.E.に随伴し得る上述のような リスクと他方効用を併せ考慮した場合，P.E.を TTP に対する第一選択とするには尚実積に乏し いが，抗血小板剂，CS 等の応用が無効と判断され た場合，速やかにP.E.を実施しても必ずしも不穏 当とは言い得ない，或いはむしろこの時点で積極 的に考慮すべきであろう。

尚, 寛解後の維持療法には CS や抗血小板剂が 多く使われて扣り，自験例も DPM, TP にて維持 療法とした. Myers ら ${ }^{75)}$ は前述した部分寛解の症 例はもちろん, 完全寛解状態でも subclinical に TTP の病態が存続すると考兄て， 6 力月～ 1 年 は少なくとも維持療法を続けるべきとしている.

(ii） P.E.の効果発現機序について

この時点に関しては，有害物質の “除去”之他 方欠如物質の “補給” の両面が想定され, 病因追 求とも関連して興味あるところである，有害物質 としては $\mathrm{PAF}^{3 / 4)}$ の存在がいわれ，また前述した

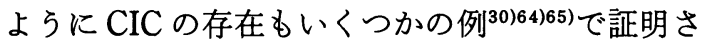
れている，後者としては血管壁からのプロスタサ イクリン様物質の放出の欠如 ${ }^{78)}$, PAF inhibitor の欠如3)がいわれ，事実血㓡輸注のみで軽快した 症例348)79) 報告されている。ささらに FFP 以外の 置換液が無効であることを考えれば，有害物質の 除去のみでは P.E.の作用機序は説明し難く，欠如 物質の補給が大きな意義を有すると考えられる。
自験例でも循環血流中に PAF 様物質の存在が想 定されることは既に述べた。 また最近 von Willebrand 因子の large multimers が TTP の発症, 再発に関与するとの報告(4)80 みられ,ここでは一 次的に血管内皮細胞の障害が想定されている.

しかしながら，これら因子はTTP のほとんど 大部分を占める “急性型” 症例では, 循環血流中 にもっぱら一過性に出現すると考えられる。すな わち，“急性期”をP.E.で対処し，寛解に到達すれ ば，血流中にはもはや上述のような因子は証明さ れないとされゆえにこれらの病的過程をもたら した本来の病因はこの間に自然に “霧散”すると 考えられる。

他方, 少数例ではあるが, P.E.にても寛解に到達 し得ない症例が知られ，これらに対しては摘脾 ${ }^{52)}$, intact immunoglobulin 大量療法が有効であった との報告も見られる。

総じて, P.E.が他の薬物や手法に優る有用性は, ほとんど疑いもないが，本邦では尚症例が少なく 実積に乏しいと言えよう，上述の様にP.E.に反応 せず，摘脾その他に反応する少数例の存在など, TTP に対する治療法とその選択枝の若干の多様 性は, TTP が均質な一疾患群といらょりも, 先に 触れた如く，不均質な疾患群より成るやや粗な概 念にとどまる以上，むしろ当然の帰結と言えよう。

\section{結語}

P.E.により救命的効果を得，その後完全寛解を 維持している TTP の 1 例を報告し, 次いで本邦 報告 TTP 例の臨床病理学的検討をあわせ行な い, TTP の疾患概念並びに治療法を考察し，特に P.E.の有用性を強調した。

本論文の要旨の一部は, 第18回国際輸血学会一ミュンへ ン, 1984年一, 第26回日本臨床血液学会一名古屋, 1984年 一で報告した。

\section{文献}

1) Moschowitz, E.: An acute febrile pleichromic anemia with hyaline thrombosis of terminal artorioles and capillaries: An undescribed case. Arch. Inter. Med., 36 : 89-93, 1925.

2) 猪瀬 正：脳症状を呈した紫斑病の 1 特異例。脳 と神経, $2: 120-124,1949$.

3) Lian, E.C.-Y., et al.: Presence of a platelet aggregating factor in the plasma of patients 
with thrombotic thrombocytopenic purpura (TTP) and its inhibition by normal plasma. Blood, 53 : 333-338, 1979.

4) Kelton, J.G., et al.: Detection of a plateletagglutinating factor in thrombotic throm. bocytopenic purpura. Am. Inter. Med., $101: 589$ $-593,1984$.

5）古池保雄, 他：Aspirin おょび Dipyridamole に より寛解した血栓性血小板減少性紫斑病（T.T P.) の一治験例. 名医学, $97: 36-43,1974$.

6）石丸博明，他：血栓性血小板减少性紫斑病之小人 症を伴った SLE の一症例. 内科宝函, $22: 25-34$, 1974.

7）石津久左衛門，他：血栓性血小板减少性紫斑病の 1 例. 日内会誌, $64: 719-720,1975$.

8）高原 耕, 他: Thrombotic thrombocytopenic purpura の 1 剖検例. 日内会誌, $64: 289-290$, 1975.

9）野田一雄, 他：脳橋その他脳内各部に小軟化巣を 認めた thrombotic thrombocytopenic purpura の 1 剖検例. 日内会誌, $64: 183,1975$.

10）梅田文夫, 他: Thrombotic thrombocytopenic purpura の 1 例. 九州血液研究同好会誌, $24: 69$, 1976.

11）山本修一, 他：血栓性栓球减少性紫斑病の一剖検 例。新潟医学会雑誌，90：605, 1976.

12）藤森一平, 他：血栓性血小板減少性紫斑病(TTP) を初発症状とした SLE の一例. 厚生省特定疾患全 身性エリテマトーデス・シェグレン病調査研究斑, 昭和50年度研究業績, $165-168,1976$.

13）近藤 武, 他：血栓性血小板減少性紫斑病の一剖 検例。診療之新薬, $18: 311-316,1977$.

14）上田峻弘, 他：血栓性血小板減少性紫斑病(TTP) の 1 剖検例. 臨床血液, $18: 73-80,1977$.

15）桶口晶文, 他：Dipyridamole, Aspirin で寛解を きたした血栓性血小板減少性紫班病の 1 治験例. 診断と治療, $65 ： 1947-1954,1977$.

16）貞元春美, 他：急性肝炎を併発して治瘜した血栓 性血小板減少性紫斑病. 臨床と研究, 54 : 516-520, 1977.

17）吉田治義, 他：Thrombotic Thrombocytopenic purpura (TTP) と SLE の合併した 1 剖検例. 日 血会誌, $40: 371-372,1977$.

18）青才文江, 他：小児に括ける Hemolytic uremic syndrome $\prec$ thrombotic thrombocytopenic purpura の検討. 小児科臨床, $31: 227-235,1978$.

19）長坂一三，他：抗核抗体の出現を認め, プレドニ ゾロン,アスピリン併用療法にて宽解を得た TTP と思われる 1例. 日内会誌, $67 ： 1238,1978$.

20）中沢深雪，他：多彩な精神神経症状を呈した thrombotic thrombocytopenic purpura (TTP) の 1 剖検例。 日内会誌, $67: 110,1978$.
21）森岡正信，他：血小板機能抑制剂にて寛解した血 栓性血小板減少性紫斑病の 2 例. 臨床血液, 19 ： $704,1978$.

22）瀬谷 司, 他: アスピリン, ジピリダモールが著 効を奏したTTPの一症例。臨床と研究，56： 920-924, 1979.

23）須田啓一，他：血栓性血小板減少性紫斑病様症状 を伴った全身性エリテマトーデスの 1 例. 内科, $44: 500-504,1979$.

24) 大内栄悦, 他: Systemic lupus erythematosus (SLE) K thrombotic thrombocytopenic purpura （TTP）を合併したと考えられる 2 症例。臨床血 液, $20: 918-927,1979$.

25）小西慎吾, 他：ブレドニン, azathiopurine により 長期寛解が得られた。血栓性血小板減少性紫斑病 と思われる 1例。日内会誌, $68 ： 807,1979$.

26）降旗謙一, 他：歯肉生検で血栓性血小板减少性紫 斑病 (TTP) が診断されたステロイド, アスピリ ン,ダイピリダモールが奏効した SLEの 1 例. 日 内会誌, $68: 1373-1374,1979$.

27）島田秀夫, 他：中枢神経症状を伴わず，骨䯣生検 組織像から診断しえた TTP の 1 症例。臨床血液, 20 (補冊 I)：272, 1979.

28）田中広, 他：血栓性血小板减少性紫斑病(TTP) の 3 症例。臨床血液, 20 (補冊 I)：272，1979。

29）中山 他：女珄ホルモン剂過剩投与によると 考光られる TTP 様血液異常の 1 症例. 臨床血液, $20: 1000-1001,1979$.

30）深沢啓治, 他: Circulating immune complex （CIC）が高値を示し，抗血小板療法が奏効した thrombotic thrombocytopenic purpura (TTP) の 1 小児例。臨床血液, $21: 1566-1574,1980$.

31）多田豊曠,他：抗血小板抗体陽性で SLE に合併し た血栓性血小板减少性紫斑病 (TTP)の一剖検例. 臨床血液, $21: 1773-1780,1980$.

32）末永諭介, 他：血浆交換が著効を示した血栓性血 小板減少性紫斑病. Immunohaematology, 2： 367-372, 1980.

33）石毛憲治, 他: Thrombotic thrombocytopenic purpura (TTP)の 2 症例. 日内会誌, $69: 406$, 1980.

34）小沢英輔, 他：血栓性血小板减少性紫斑病の 1 例. 日内会誌，69：406，1980。

35）小林研介, 他：血栓性血小板减少性紫斑病の 1 症 例. 日内会誌，69：406-407，1980.

36）桶口英嗣, 他：血栓性血小板减少性紫斑病の 1 例. 日内会誌, $69: 1030,1980$.

37）伊藤孝一郎, 他：急性脳炎様の臨床経過をとり, 第 9 病日に死亡した血栓性血小板减少性紫斑病の 1 剖検例. 九州神経精神医学, $27: 55-59,1981$.

38) Hirose, Y., et al. : Intimal thickening of renal arterioles in a case of thrombotic throm- 
bocytopenic purpura: Clinical course and autopsy findings. Acta Haematol. Jpn., 44 : 173 $-182,1981$.

39）小金丸茂喜，他：ステロイドホルモンと抗血小板 剂により寛解に導入できた血栓性血小板减少性紫 斑病 (Thrombotic Thrombocytopenic Purpura : TTP)の 1 症例. 広島医学, $34: 166-173,1981$.

40）九島巳樹, 他: Systemic lupus erythematosus (SLE)に thrombotic thrombocytopenic purpura (TTP)を合併した 1 症例. 昭和医学会雑誌, 41 ： 213-217, 1981.

41）永田頌史, 他：血栓性血小板减少性紫斑病の一寛 解例一ワーファリンと抗血小板剂使用について 一。臨床血液, $22: 678-684,1981$.

42）中村克己, 他：血栓性血小板減少性紫斑病の 1 例. 臨床血液, $22 ：($ 補冊)：241，1981.

43）福田喜裕, 他：血栓性血小板減少性紫斑病の一例. 臨床血液, 22(補冊)：241，1981.

44）嵐方之, 他：強直性脊椎炎に合併した慢性 TTP の一剖検例. 臨床血液, 第23回総会抄録集, 421，1981.

45）石田陽治, 他：血栓性血小板減少性紫斑病の一剖 検例. 臨床血液，第23回総会抄録集，423，1981.

46）日野理彦, 他：輸血と副腎皮質ステロイド大量投 与により寛解を得た血栓性血小板減少性紫斑病の 2 症例. 臨床血液, 第23回総会抄録集, 423, 1981.

47）千場 純, 他：臨床的に Thrombotic Thrombocytopenic Purpura (TTP) と診断し, Dipyridamole, Urokinase および, Aspirin によって救 命しえた一例。臨床血液, $23: 671-677,1982$.

48）徳山研一, 他：血浆輸注に反応した thrombotic thrombocytopenic purpura (TTP) の 1 小児例. 日本小児科学会雑誌, $86: 1085-1091,1982$.

49）相沢 信, 他：血浆交換療法が著効した血栓性血 小板减少性紫斑病の 2 症例. 臨床血液, 23 : 1618-1623, 1982.

50）池田 洋, 他：血栓性血小板减少性紫斑病の 1 剖 検例. 愛知医大医学会雑誌, $10: 321-328,1982$.

51）坂巻 寿, 他：臨床症状が軽微で抗血小板療法が 著効を示した TTPの 1 例. 臨床血液, $23 ： 1154$, 1982.

52）永田紘一郎，他：摘脾が効を奏した興味ある TTP の一症例. 臨床血液, 第24回総会抄録集, 351, 1982.

53）小林紀子, 他：血栓性血小板减少性紫斑病の一剖 検例. 最新医学, $38: 760-766,1983$.

54) 津本清次, 他: Thrombotic thrombocytopenic purpura (TTP)の 1 例. 現代医療, 15：871-876, 1983.

55）山口悦郎, 他：副腎皮質ホルモン, ヘパリン，抗 血小板剂が奏効した血栓性血小板減少性紫斑病の 1 例. 診断と治療, $71: 1107-1110,1983$.
56）風 方之, 他：小血管に IgM の沈着が認められた 血栓性血小板減少性紫斑病の一例. 臨床血液, 24： 868-873, 1983 .

57）富山順治, 他：SLE に血栓性血小板减少性紫斑病 （TTP）を伴った一剖検例. 臨床血液, $24: 51$, 1983.

58）山田隆, 他：最近経験した血栓性血小板減少性 紫斑病(TTP)の 2 症例. 臨床血液, $24: 703,1983$.

59）坂谷則彦, 他：抗血小板剂括よび副腎皮質ステロ イドにて寛解しその後 1 年間寛解を維持している TTP の一例. 臨床血液, 第 25 回総会抄録集, 360 , 1983.

60）牧野正彦, 他：血浆交換により, 神経症状が著名 に改善した, 血栓性血小板减少性紫斑病の 1 例。 臨床血液，第25回総会抄録集，360，1983。

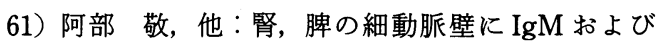
fibrinogen 沈着が認められた血栓性血小板減少性 紫斑病の 1 剖検例. 臨床血液, 第25回総会抄録集, $361,1983$.

62）山田兼雄 : Thrombotic Thrombopenic purpura (TTP) と Hemolytic Uremic Syndrome (HUS) 一その異同について. 日本臨床, $33: 3402-3410$, 1975.

63) Amorosi, E.L. \& Ultmann, J.E.: Thrombotic thrombocytopenic purpura: Report of 16 cases and review of the literature. Medicine, $45: 139$ $-159,1966$.

64) Bukowski, R.M., et al. : Plasmapheresis in the treatment of thrombotic thrombocytopenic purpura. Blood, $50: 413-417,1977$.

65）深沢啓治, 他：血栓性血小板减少性紫斑病. Immunohaematology, 2: 311-317, 1980.

66) Mant, M.J., et al.: Thrombotic thrombocytopenic purpura: Report of a case with possible immune etiology. Blood, $40: 416-421$, 1972.

67) May, H.V., et al.: Thrombotic thrombocytopenic purpura associated with pregnancy. Am. J. Obstet. Gynecol., 126 : 452-458, 1976.

68) Ridolfi, R.L., et al.: Thrombotic thrombocytopenic purpura. Medicine, $60: 413,1981$.

69) Umlas, J., et al.: Thrombohemolytic thrombocytopenic purpura (TTP). A disease or a syndrome? Amer. J. Med., 49 : 723-728, 1981.

70) Goldenfarb, P.B., et al. : Thrombotic thrombocytopenic purpura: A ten-year survey. JAMA, 226 : 644-647, 1973.

71) Jacob, A., et al.: Treatment of thrombotic thrombocytopenic purpura with antiplatelet drugs. Blood, 42 : 27-32, 1973.

72) Eckel, R.H., et al.: Platelet-inhibiting drugs in thrombotic thrombocytopenic purpura. 
Arch. Intern. Med., 137 : 735-737, 1977.

73) Cuttner, J.: Thrombotic thrombocytopenic purpura : A ten-year experience. Blood, 56 : 302 $-306,1980$.

74) Bukowski, R.M., et al. : Therapy of thrombotic thrombocytopenic purpura : An overview, Sem, Hemostaiss, $7: 1-8,1981$.

75) Myers, T.J., et al.: Thrombotic thrombocytopenic purpura: Combined treatment with plasmapheresis and antiplatelet agents. Ann. Inter. Med., 92 : 149-155, 1980.

76) Harkness, D.R., et al. : Hazard of platelet transfusion in thrombotic thrombocytopenic purpura. JAMA, 246: 1931-1933, 1981.

77）湯浅晋治：プラズマフェレーシスに伴う合併症,
副作用とその頻度. 日本臨床, $42: 1920-1929$, 1983.

78) Machin, S.J., et al.: A plasma factor inhibiting prostacycline-like activity in thrombotic thrombocytopenic purpura. Acta Haemat., 67 : 8-12, 1982.

79) Byrnes, J.J., et al.: Treatment of thrombotic thrombocytopenic purpura with plasma. N. Engl. J. Med., 297 : 1386-1389, 1977.

80) Moake, J.L., et al.: Unusually large plasma factor VIII : von Willebrand factor multimers in chronic relapsing thrombotic thrombocytopenic purpura. N. Engl. J. Med., 307 : 1432-1435, 1982. 